\title{
GEOGRAPHIC RECORD OF HUMAN IMPACT CONFORMANCE TO DIFFERENT WATER RELATIONSHIPS ALONG A COASTAL RIVER (THE ŁUPAWA CATCHMENT)
}

\author{
Jan Drwal, Roman Cieśliński, Joanna Fac-Beneda \\ University of Gdańsk, Department of Hydrology, Gdańsk, Poland
}

Manuscript received: November 25, 2010

Revised version: February 15, 2011

\begin{abstract}
DRWAL J., CieśLIŃski R., FAC-BENEDA J., 2011. Geographic record of human impact conformance to different water relationships along a coastal river (the Łupawa catchment). Quaestiones Geographicae 30(1), Bogucki Wydawnictwo Naukowe, Poznań, pp. 19-29, 12 Figs. ISBN 978-83-62662-39-5. ISSN 0137-477X. DOI 10.2478/v10117-011$0002-4$.

AвSTRACT. The purpose of this paper is to answer the following two questions: Can one infer the type of human impact found in the northern Pomorze region from the current state of the Łupawa basin? Did regional water relationships determine the type of human impact found in the area? A good place to search for an answer to these two questions is the Eupawa River drainage basin. The entire upper section of the river, upstream from the Bukowina, is characterized by a lack of substantial changes in the hydrographic network, resulting from man's apparent disinterest in the area. The middle section of the river is characterized by human impact in the form of the use of water resources for energy generation purposes (sawmills, gristmills, power plants). The lower section of the Łupawa that includes Lake Gardno is characterized by significant changes in water relationships associated with difficult discharge conditions. Finally, the mouth section of the river, given its location, has been adapted as a port facility.
\end{abstract}

KEYWORDS: Łupawa, course of river, valley, elementary hydrographic structure, human impact

Jan Drwal, Roman Cieśliński, Joanna Fac-Beneda, University of Gdańsk, Department of Hydrology, Bażyńskiego 4, 80-952 Gdańsk,Poland, geojd@univ.gda.pl, georc@univ.gda.pl, geojfb@univ.gda.pl

\section{Introduction}

Rivers flowing down the hill slopes of the northern Pomorze Lake District flow across areas that differ substantially in terms of water relationships before emptying into Poland's main drainage basin, the Baltic Sea.

Coastal rivers in Poland originate in the headwater areas of acentric hydrographic systems (Drwal 1982). The rivers' upper and middle course runs down the hill slopes of the Pomorze Lake District where the terrain gradient can reach 250 m (Karczewski 1988, Borówka 1995). Their lower course runs across alluvial plains that rise minimally $(0.2-0.3 \mathrm{~m})$ above sea level (Drwal et al. 2007). Polish coastal rivers empty into the Baltic Sea, and in some cases, serve as points of entry for seawater intrusions (Cieśliński \& Drwal 2005). Each section of river plays a specific hydrological role (function) in the formation of discharge - the functions being described by a hydrographic system cascade model for land-based water (Drwal \& Hryniszak 2003). It can be hypothesized that it is the rivers' hydrological functions that deter- 
mine the type of human impact on the water relationships found in the northern Pomorze Lake District.

The river network in the northern Pomorze region has been experiencing ongoing natural evolution processes since the end of the Pleistocene. In more recent times, man has made his impact strongly felt in the region in a variety of ways, especially since the second half of the $19^{\text {th }}$ century. The river network's current state found on large scale maps is a geographic record of some of these processes.

The purpose of this paper is to answer the following two questions: Can one infer the type of human impact found in hydrological network in the Łupawa basin? Did regional water relationships determine the type of human impact found in the area?

\section{Research Area}

The Łupawa River is $98.7 \mathrm{~km}$ long and has a drainage basin of $964.4 \mathrm{~km}^{2}$ (Fig. 1). Along its course, it is joined by larger tributaries such as the Bukowina (flowing from Mydlita village), the Rokitnica, the Rębowa, the Darżyńska Struga, and the Charstnica. The average terrain gradient along the Łupawa is $2 \%$. The river discharges water into Lake Gardno at an average rate of 8.2$8.3 \mathrm{~m}^{3} \mathrm{~s}^{-1}$ (Cyberski \& Jędrasik 1992, Choiński \& Kaniecki 2003, Bogdanowicz 2004). The discharge rate varies from $7.04 \mathrm{~m}^{3} \mathrm{~s}^{-1}$ in August to $9.44 \mathrm{~m}^{3} \mathrm{~s}^{-1}$ in March (Jereczek-Korzeniewska 2005). Floods take place in February and March (snowmelt) and in the summer and autumn (rainfall). Low water states appear in June and July.

It is generally accepted that the course of the Łupawa can be divided into an upper, middle, and

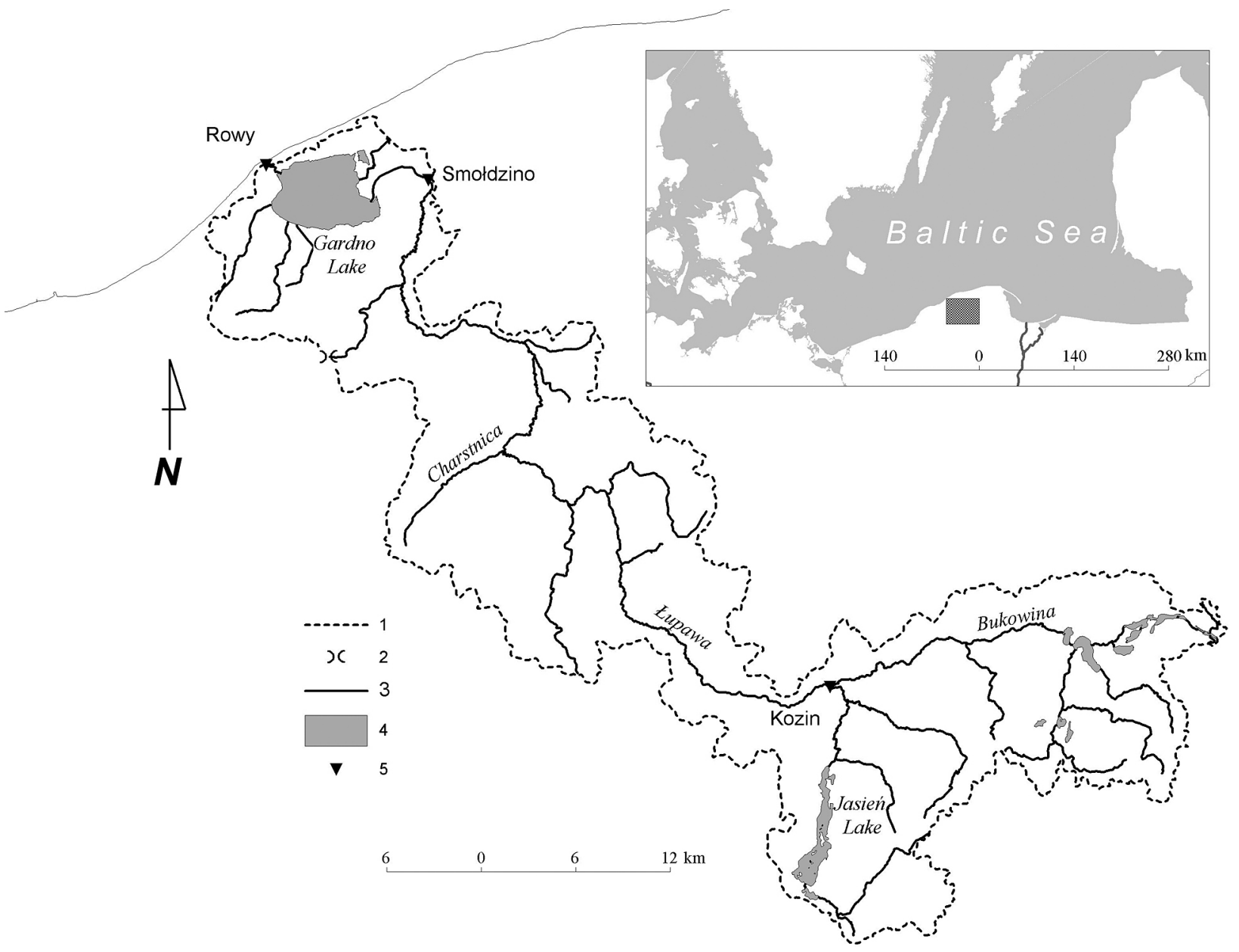

Fig. 1. Łupawa River drainage basin

Legend: 1 - drainage divide, 2 - water gate, 3 - streams, 4 - reservoirs, 5 - water level recorder 
lower section. Therefore, it can be said that the upper section of the Łupawa formed within a terminal moraine zone, reaching $250 \mathrm{~m}$ above sea level. The river flows out of Lake Jasien at an elevation of $202 \mathrm{~m}$ and flows down through a former subglacial gully. The river's middle course runs through valleys of different origin and age, which tend to be connected mainly with marginal and proglacial discharge (Sylwestrzak 1978, Florek 1993, Rotnicki 2001). The lower course of the river runs across flat terrain featuring peat bogs and swamps. The river first flows into Lake Gardno and then exits the lake and finally proceeds to the sea. The stretch linking Lake Gardno and the Baltic Sea is really a canal, which cuts across a "Gardno Phase" marginal ice cap zone.

\section{Research Process}

The research process was conducted in several stages. The first stage consisted of the identification of sections of the Eupawa River that are different in terms of their hydrological function expressed by the hydrographic structure. The drainage basin's elementary hydrographic structure was adopted as the criterion to be used in the identification process, as it reflects water relationships in a systematic way (Drwal 1982). An understanding of the area's hydrographic structure allows one to estimate average rates of discharge (both surface and base) from hydrometrically unmonitored areas (Drwal 1982). The average total rate of discharge was estimated using the runoff reduction method, subtracting the constant $R_{Q}$ in line with decreasing stream order (Drwal 1982). The next stage consisted of the identification of the forms of human impact present in the area (Fac-Beneda 2005a, 2007).

In order to accomplish identification of the form of human impact, a list of all anthropogenic hydrographic entities and river engineering structures was compiled by way of a query of primary sources and the associated literature, the results of which were verified in the field. The next stage consisted of a plan to divide the valley of the Łupawa River into an upper, middle, lower, and mouth section. The last stage consisted of a selection of representative sites along each section of river.

\section{The Łupawa Valley}

The division of the Łupawa River valley into four sections is based on the elementary hydrographic structure of its drainage basin. The hydrographic structure reflects the different drainage conditions found in each part of the Łupawa River drainage basin, thus determining the function of each particular section of river being fed by a particular part of the total drainage basin.

The Łupawa River forms an eighth order hydrographic system. Up to the gauge cross-section hydrometric site in Smołdzino (seventh order) (Fig. 2), located in the upland part of the drainage basin, the river's elementary hydrographic structure is dominated by permanent tributaries $(24 \%)$, absorbent drainage-free areas $(22 \%)$, and permanent drainage basins (20\%).

Drainage-free evapotranspiration areas and temporary tributaries each constitute only $14 \%$ of the river's hydrographic structure, while temporary drainage basins make up only $2 \%$. Areas that collect water such as the different sections of the Łupawa Valley as well as the valleys of its tributaries (fourth order or higher) constitute 4\% of the hydrographic structure (Fig. 3).

The river starts out as a small, partially channelized, forest stream. Once it reaches fifth order, it enters a wide valley where it is joined by three right bank tributaries: the Otnoga (fourth order), the Rokicianka (fourth order), and the Bukowina (sixth order). Downstream from the village of Kozin, the Łupawa River becomes a seventh order river. At this location, its drainage basin becomes characteristically narrow (Fig. 4). Up to this point, the area of the drainage basin is $366 \mathrm{~km}^{2}$. Stream network density reaches $0.82 \mathrm{~km} \mathrm{~km}^{-2}$, although it is higher in the Bukowina drainage basin with $0.94 \mathrm{~km} \mathrm{~km}^{-2}$. Average total annual discharge is $261,748,800 \mathrm{~m}^{3}\left(22.7 \mathrm{dm}^{3} \mathrm{~s}^{-1} \mathrm{~km}^{-2}\right)$.

Drainage-free areas $\left(146.2 \mathrm{~km}^{2}\right.$ or $\left.40 \%\right)$ make up a large portion of the river's elementary hydrographic structure including $106.2 \mathrm{~km}^{2}$ of drainage-free evapotranspiration areas. It has been estimated that the average annual discharge from surface-drained areas - permanent and temporary drainage basins as well as permanent and temporary tributaries - is $157,315,090 \mathrm{~m}^{3}$ $\left(13.6 \mathrm{dm}^{3} \mathrm{~s}^{-1} \mathrm{~km}^{-2}\right)$. This corresponds to a base discharge of $104,433,710 \mathrm{~m}^{3}$. These data suggest that 


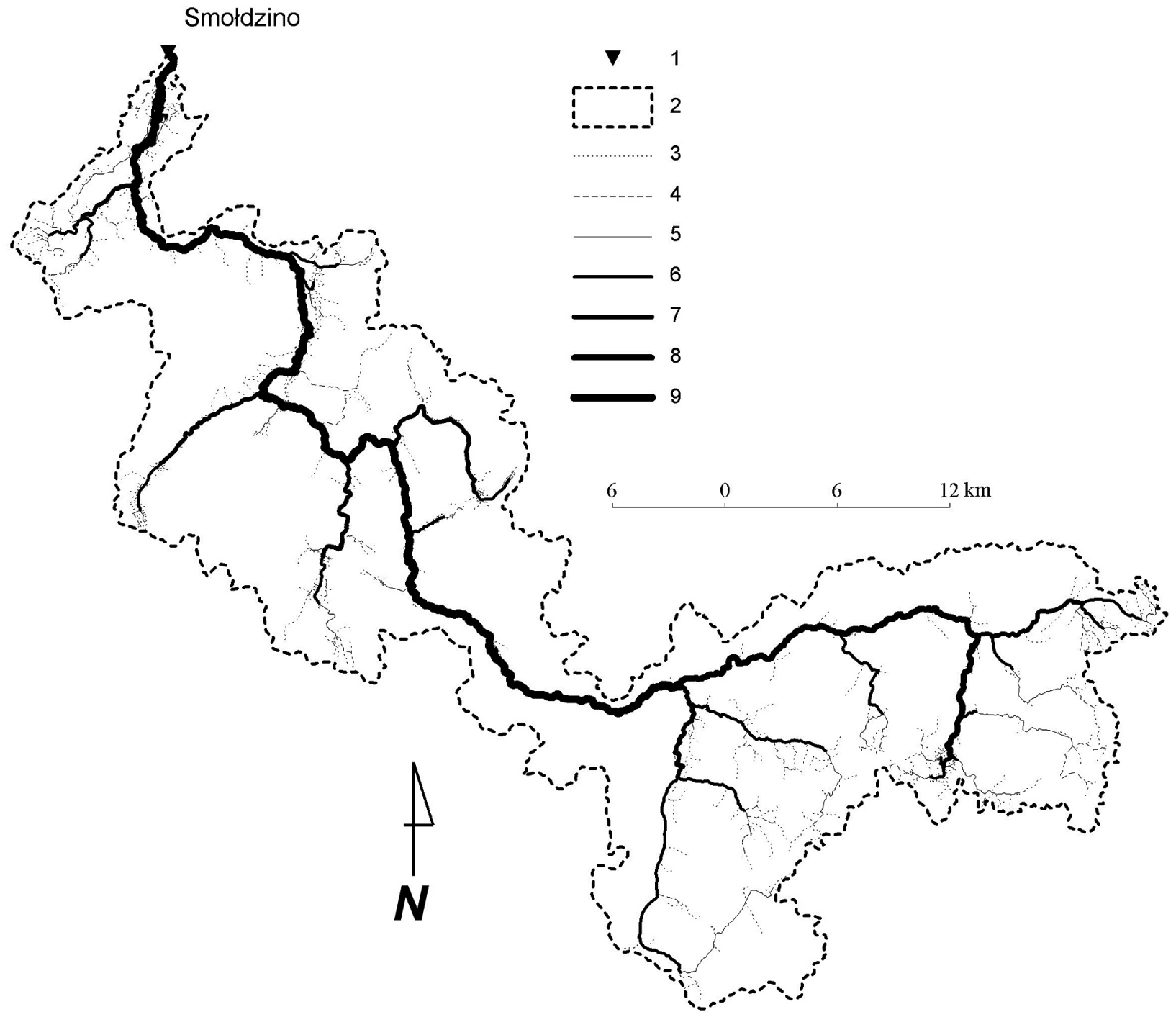

Fig. 2. River network hierarchy in the Łupawa drainage basin up to the hydrometric site in Smołdzino Legend: : 1 - water level recorder, 2 - drainage divide, 3 - the 1 st order streams, 4 - the $2^{\text {nd }}$ order streams, 5 - the $3^{\text {rd }}$ order streams, 6 - the $4^{\text {th }}$ order streams, 7 - the $5^{\text {th }}$ order streams, 8 - the $6^{\text {th }}$ order streams, 9 - the $7^{\text {th }}$ order streams

it is the fragment of Łupawa's drainage basin upstream from the village of Kozin that serves as its headwater area, while the main receiving area, which is the Łupawa Valley, could be considered the river's upper course.

Downstream from the village Kozin, the Łupawa is joined by several tributaries including the Słupinka, the Charstnica, the Brodniczka, a stream from Podole, a stream from Potęgowa, a stream from Grąbków, and a stream from Wielka Wieś. The streams do not alter the order of the Łupawa, which the river had reached downstream from the village of Kozin (270 m downstream from the Kozin water level recorder on the Bukowina), as each stream is either order four or order five. The area drained by this section of the
Łupawa is $438.9 \mathrm{~km}^{2}$. The stream network density is the same as earlier: $0.85 \mathrm{~km} \mathrm{~km}^{-2}$.

The average total recorded discharge is also $261,748,800 \mathrm{~m}^{3}$. This portion of the drainage basin is characterized by a smaller drainage-free area of $142.5 \mathrm{~km}^{2}(32.5 \%)$, including $73.9 \mathrm{~km}^{2}$ of evapotranspiration drainage-free areas. This fragment of the Eupawa drainage basin can be thought of as the middle drainage basin. The section of river that drains this part of the basin and transports water from upstream sections can be thought of as the middle course (Fig. 5).

The Łupawa is an eighth order river between the of village Smołdzino and the point where it exits Lake Gardno. This part of the drainage basin only rises $20-30 \mathrm{~m}$ above sea level. The ab- 


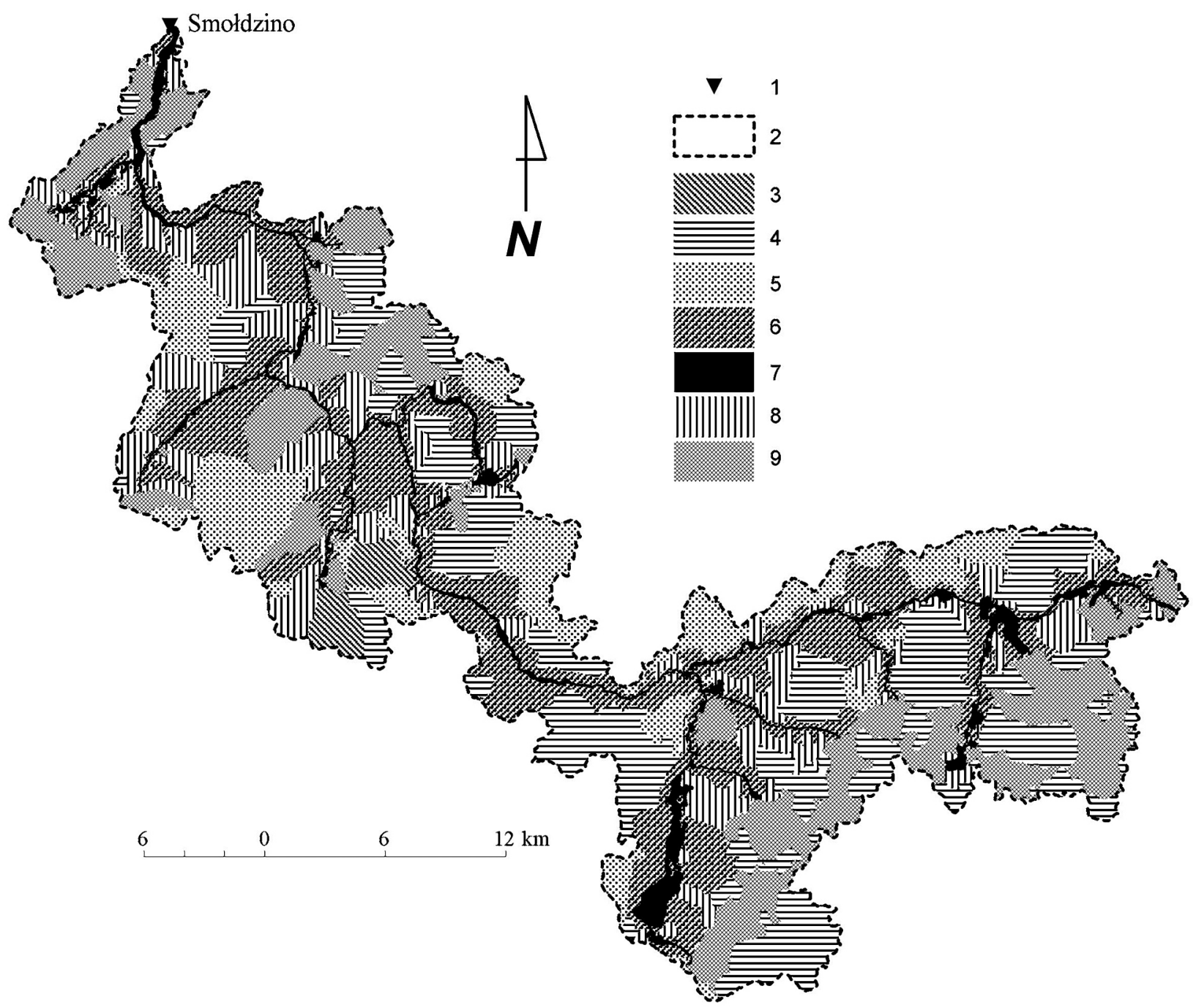

Fig. 3. Elementary hydrographic structure of the Łupawa up to the Smołdzino hydrometric site Legend: 1 - water level recorder, 2 - drainage divide, 3 - temporary drainage basin, 4 - drainage-free evapotranspiration areas, 5 - absorbent drainage-free areas, 6 - temporary tributaries, 7 - collection area, 8 - permanent tributaries, 9 - permanent drainage basin

sence of large terrain gradients makes discharge difficult. The river cuts into an adjacent upland, which may help it attract groundwater from distant circulation horizons, analogously to the case of the Reda-Łeba proglacial valley (Drwal 1982). Excess water is channeled away via a well-developed canal network. There are also five polders around Lake Gardno.

According to the classification system proposed for the Wisła River Delta by Fac-Beneda (2005b), this type of area can be classified as an anthropogenic hydrographic entity, which has one polder exit and two polder inlets, including one with gravitational influx. This part of the drainage basin has an area of $117.6 \mathrm{~km}^{2}$. Stream network density reaches $2.1 \mathrm{~km} \mathrm{~km}^{-2}$. The specif- ic discharge in this particular area is comparable to that provided in other publications including Bogdanowicz (2004) and Marszelewski (2007). The former lists a specific discharge of $10.3 \mathrm{dm}^{3} \mathrm{~s}^{-1}$ $\mathrm{km}^{-2}$ (for 1989-1998) while the latter lists a value of $10.6 \mathrm{dm}^{3} \mathrm{~s}^{-1} \mathrm{~km}^{-2}$ (for 1971-1990). We propose that this part of the Eupawa drainage basin be considered the river's lower drainage basin. We further propose that the section of the Łupawa including Lake Gardno, which drains the river's lower basin and channels water from its upper and middle basin, be considered the river's lower course (Fig. 6).

Finally, we propose that the section of river that links Lake Gardno with the Baltic Sea be considered a mouth section. This section is $1.2 \mathrm{~km}$ 


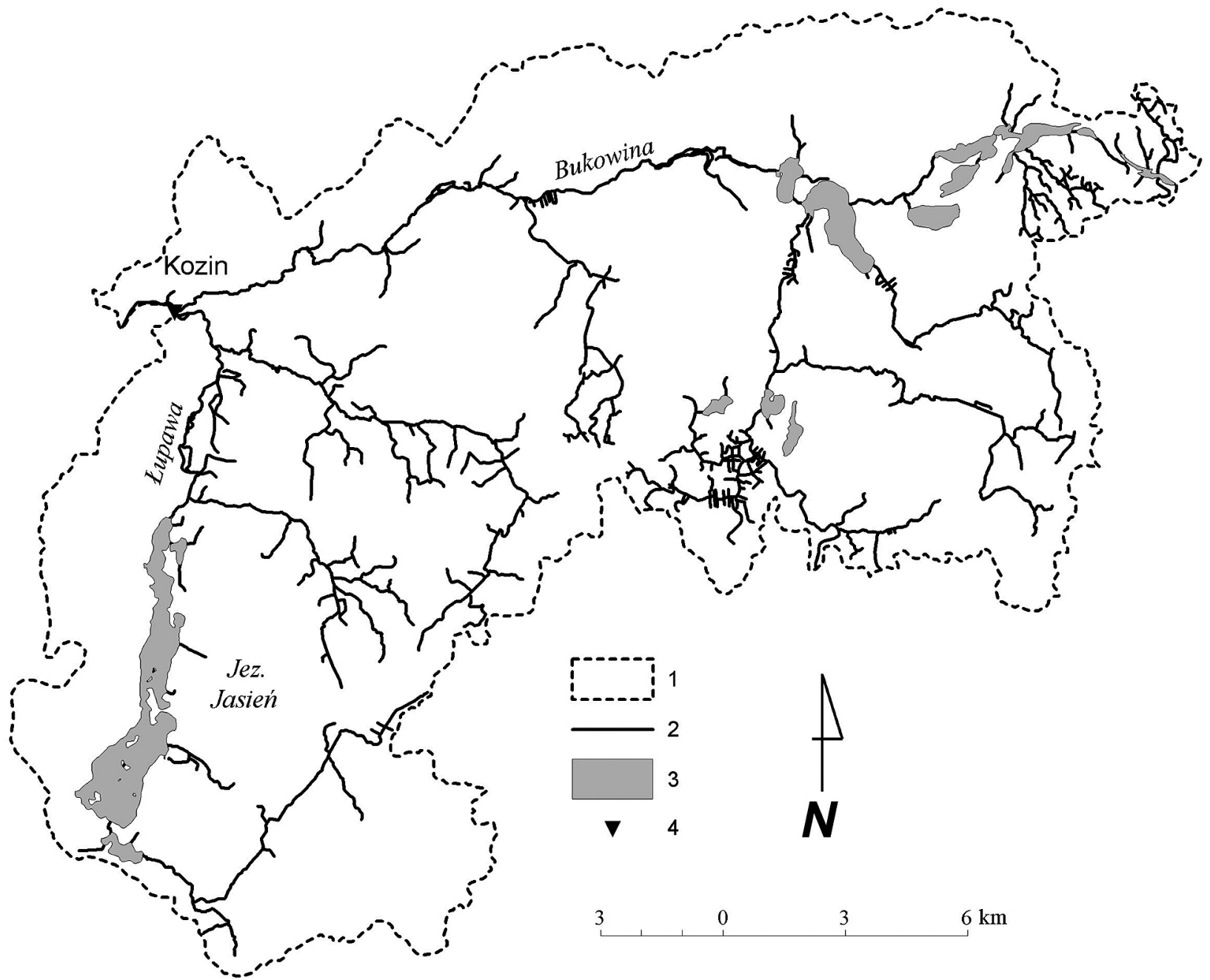

Fig. 4. Drainage basin of the upper Łupawa up to the town of Kozin and downstream from the Bukowina River Legend: 1 - drainage divide, 2 - streams, 3 - lakes, 4 - hydrometric site

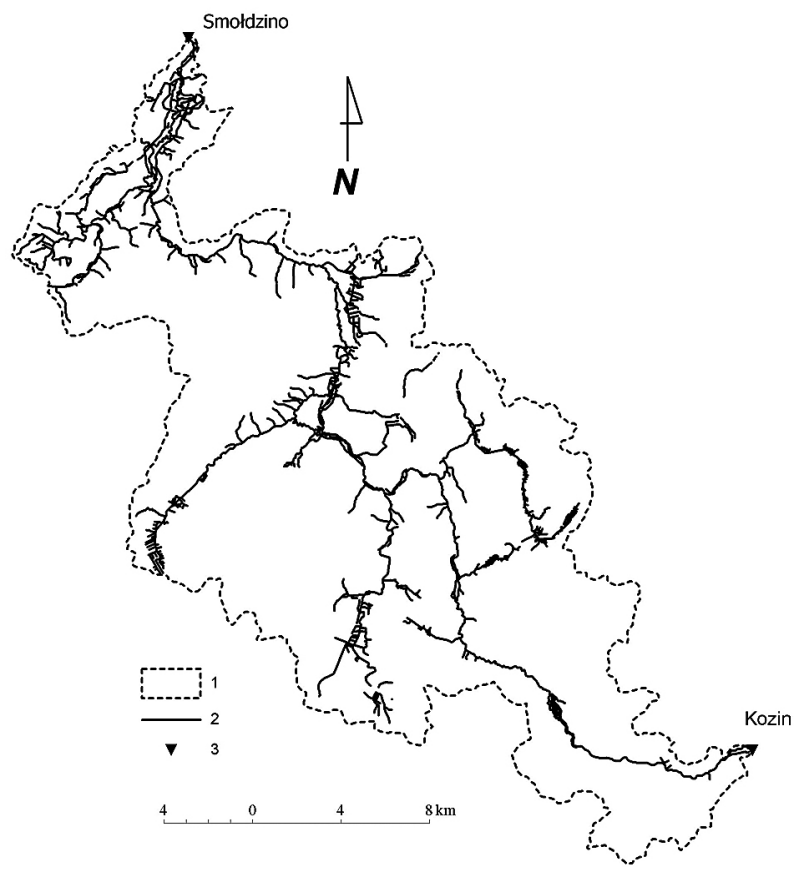

long, $36 \mathrm{~m}$ wide, and at most $2.5 \mathrm{~m}$ deep, with depth varying a mere $70 \mathrm{~cm}$. It is de facto a NWSE canal, which often suffers from excess mud content and becomes nearly impassable at low water states.

Its longitudinal slope is small - on the order of $0.3 \%$. It is different from all the other sections of the river because of the seawater intrusions that take place therein. Such intrusions can reach as far as Lake Gardno and have formed a reverse delta in the lake. The intrusions also limit potamic influx. Normal (sea bound) flow rates ranged from 10 to $20 \mathrm{~m}^{3} \mathrm{~s}^{-1}$ in 2002-2008. Reverse flow

Fig. 5. Middle drainage basin of the Łupawa River, stretching from the hydrometric site $270 \mathrm{~m}$ downstream from Kozin to Smołdzino

Legend: 1 - drainage divide, 2 - streams, 3 - hydrometric sites 


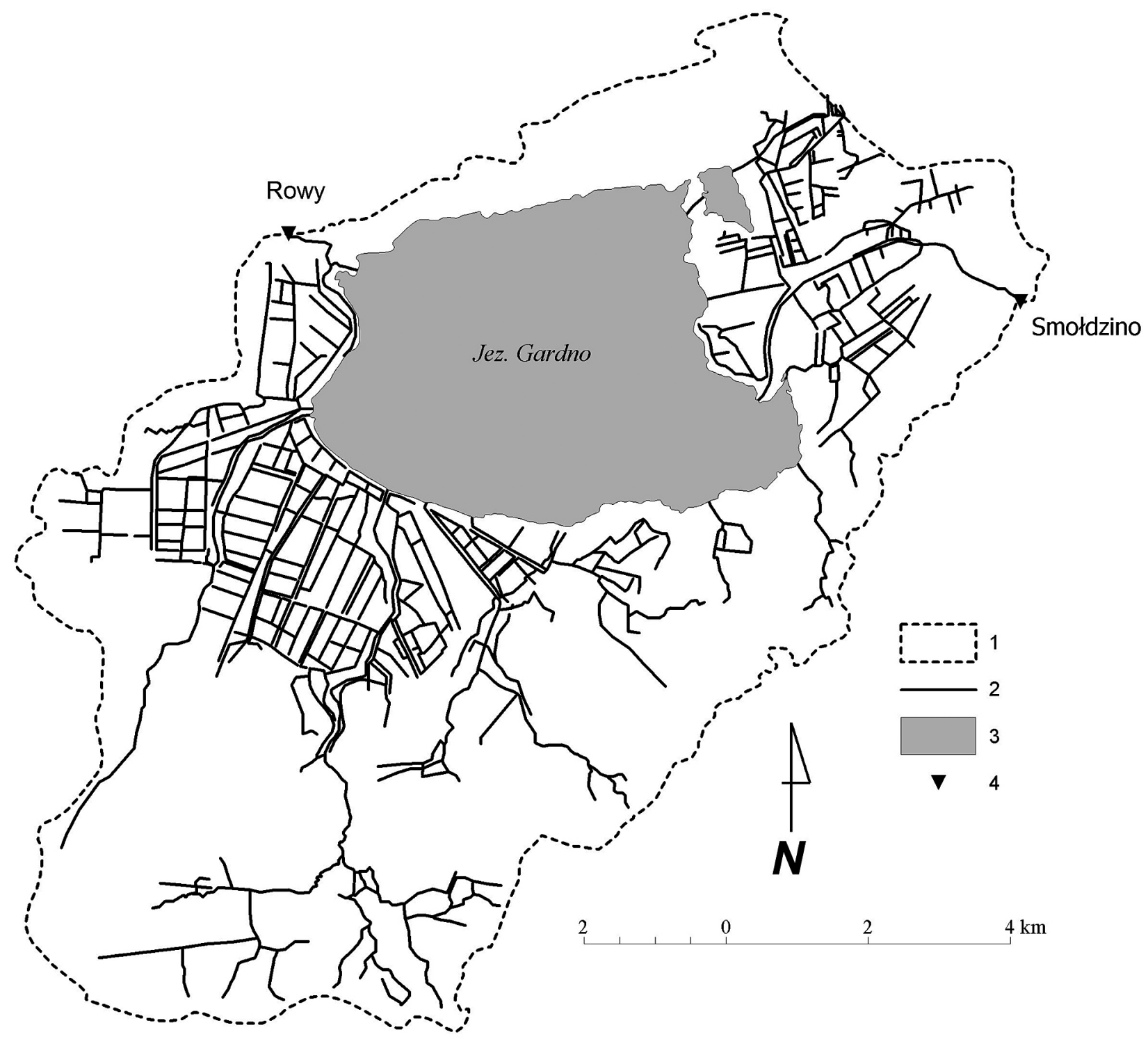

Fig. 6. Lower Łupawa drainage basin (Smołdzino - Rowy)

Legend: 1 - drainage divide, 2 - streams, 3 - lakes, 4 - hydrometric sites

(lake bound) rates reached as much as $30 \mathrm{~m}^{3} \mathrm{~s}^{-1}$ during the same time period.

Conformance of human impact to water relationships in selected valley sections

The entire upper stretch of the Eupawa River is characterized by an absence of any meaningful manmade changes. The only forms of human impact on water relationships in the area are agriculture and the release of wastewater.

The middle section of the Łupawa Valley was first used for building mills and later for building power plants. Six hydroelectric plants were built along a $59 \mathrm{~km}$ long stretch of the river. The power plants' total generating capacity is 0.94 MW. All six plants operate without reservoirs us- ing a flow-through system. The plants' turbines discharge water at about the same rate. Only the turbines located in the upper section of the middle course of the Łupawa River produce larger discharge rates.

The Smołdzino hydroelectric plant is the second largest power plant along the Łupawa River. A sawmill and a gristmill were built here at the end of the $16^{\text {th }}$ century. The gristmill was shut down in the 1950s and later adapted to irrigation purposes. The power plant has two turbines that discharge water at $4.0 \mathrm{~m}^{3} \mathrm{~s}^{-1}$ and $8.25 \mathrm{~m}^{3} \mathrm{~s}^{-1}$. The largest power plant along the Łupawa is the Żelkowo plant located along kilometer 31.0 of the river. The plant was built in 1907-1909 and 
equipped with two turbines, each with a discharge rate of $5.3 \mathrm{~m}^{3} \mathrm{~s}^{-1}$.

The Drzeżewo hydroelectric power plant is located along kilometer 36.0 of the Łupawa River and has been around since 1925. At first, the dam was used to run a mill and produce electric power. The power plant is equipped with a 175 $\mathrm{kW}$ turbine that discharges water at a rate of 6.70 $\mathrm{m}^{3} \mathrm{~s}^{-1}$.

The Łebien hydroelectric power plant is located along kilometer 52.0 of the Łupawa River. The dam has been around since 1933 and was initially used to generate electric power as well as to run a mill that burned down during World War II. The power plant is equipped with a $50 \mathrm{~kW}$ turbine that discharges water at a rate of $5.74 \mathrm{~m}^{3} \mathrm{~s}^{-1}$.

The Poganice hydroelectric power plant is located along kilometer 54.4 of the Łupawa River. It also uses a dam originally built for a mill that no longer exists. The power plant is equipped with a turbine that discharges water at a rate of 4.64 $\mathrm{m}^{3} \mathrm{~s}^{-1}$.

The Łupawa hydroelectric power plant is located along kilometer 58.8 of the Łupawa River. It uses a dam originally built for a watermill. The former mill's turbine chamber and machinery room were adapted for power generation purposes in 1982. The power plant is equipped with a turbine that discharges water at a rate of $4.25 \mathrm{~m}^{3} \mathrm{~s}^{-1}$.

The lower section of the Łupawa River has been channelized since the $17^{\text {th }}$ century. The outcome of the channelization efforts can be seen in cartographic materials dating back to

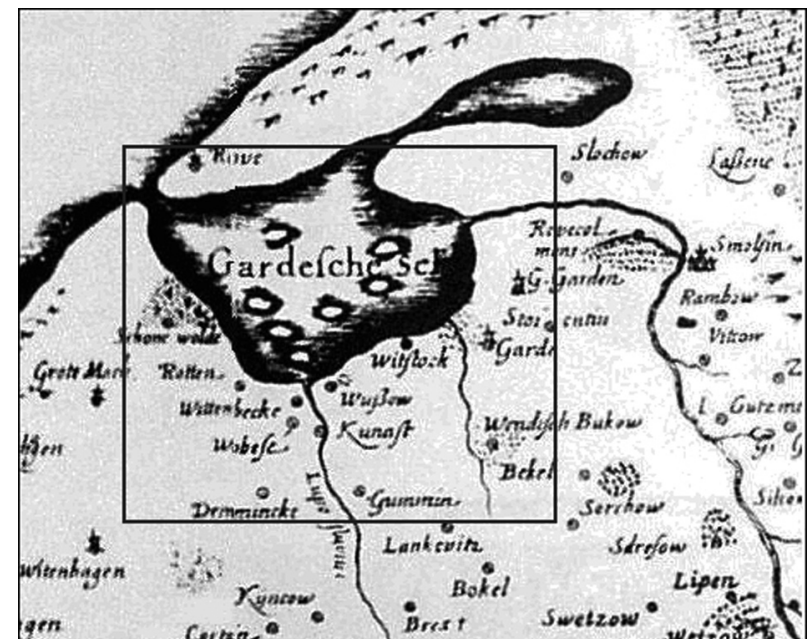

Fig. 7. Lake Gardno on the Pomeranian Principality map of Eilhard Lubinus from 1618 the $17^{\text {th }}$ century. A map produced by the Pomeranian Principality of Eilhard Lubinus (scale: 1:235,000) shows the Łupawa River flowing into Lake Gardno from the east (Fig. 7). The absence of other hydrographic entities indicates that the area was subjected to engineering efforts at the time. The Generalstabskarten von Pommerellen map (scale: 1:100,000) from 1836 shows the first ditches and canals, especially those constructed near the mouth of the river.

They were most likely designed to relieve the Łupawa River (Fig. 8). Moreover, the map shows single canals running through the town of Smołdzino, connecting the Łupawa River with the rest of the hydrographic network of the direct drainage basin of Lake Gardno.

Yet another map - the Messtischblatter map of 1891 (scale - 1:25,000) - shows even more ditches and canals. The map also shows the rivers flowing into the lake: the Grabownica, the Bagienica, and the Brodnica (Fig. 9).

An increasingly more dense canal network can be seen on the Karte des Deutschen Reiches from 1892 (scale - 1:100,000). However, one can also see that some of the ditches visible in 1891 no longer exist (Fig. 10). Modern maps (scale 1:25,000 and 1:50,000) from 1977 as well as a new hydrographic map (scale - 1:50,000) from 2006 show the current state of the hydrographic network. Between 1977 (Fig. 11) and 2006 (Fig. 12), the density of the ditch and canal network increased once again. The network is particularly dense in the Gardno Meadows area and near the

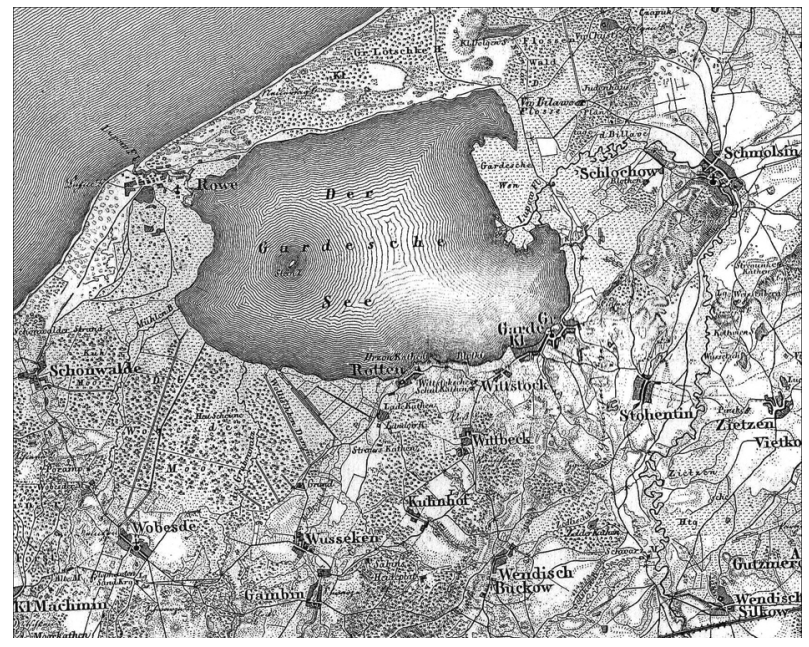

Fig. 8. Lake Gardno on Generalstabskarten von Pommerellen map from 1836 


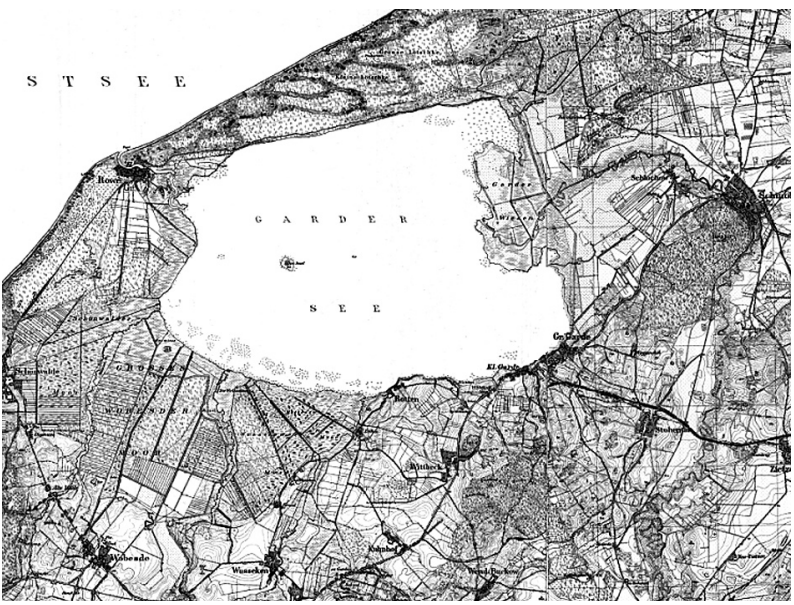

Fig. 9. Lake Gardno on the Messtischblatter map of 1891

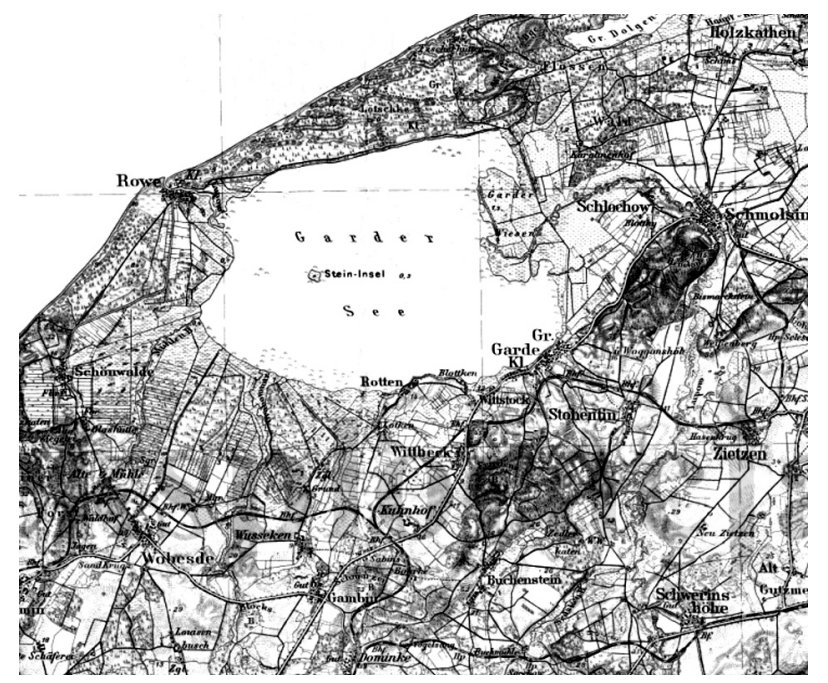

Fig. 10. Lake Gardno on the Karte des Deutschen Reiches map from 1892

Gardno-Łebsko Canal, which exits the lake to the east, near the point where the Łupawa River flows into the lake.

The lower section of the river has been substantially altered by man, with the construction of quays that serve as port facilities. There is no breakwater on the Baltic Sea that would protect the mouth of the river, and indirectly Lake Gardno, from maritime influence. The mouth section has to be dredged following storm events in order to remain passable.

\section{Conclusions}

The valley of the Łupawa River, as seen on modern large scale maps, is characterized by

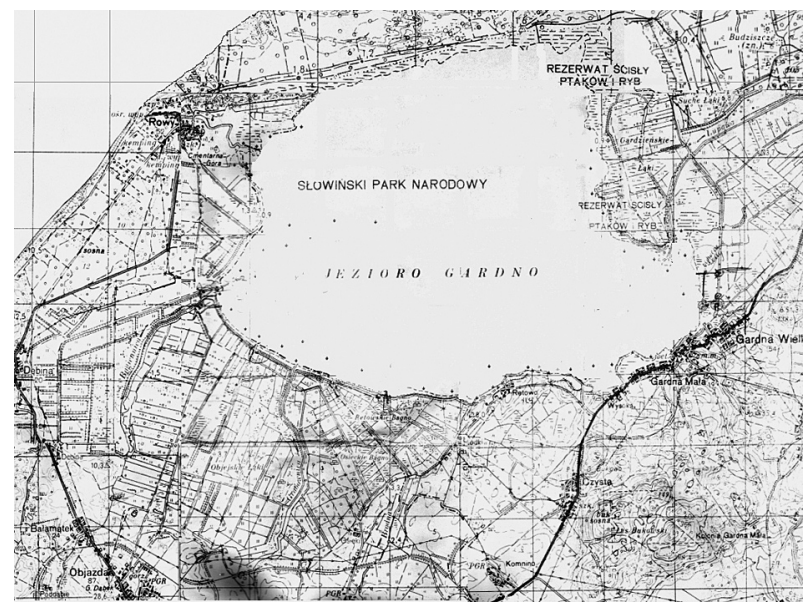

Fig. 11. Lake Gardno on the topographic map from 1977

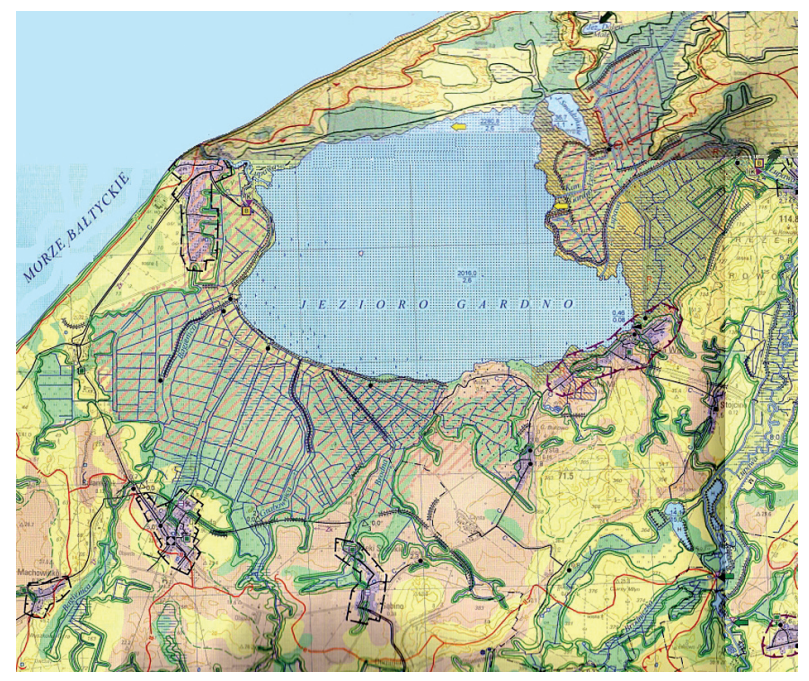

Fig. 12. Lake Gardno on the hydrographic map from 2006

a diverse hydrographic network, which makes it possible to connect its appearance to the different forms of human impact brought about by the unique water relationships found in each section of the valley.

The entire upper section of the river, upstream from the Bukowina, is characterized by a lack of substantial changes in the hydrographic network, resulting from man's apparent disinterest in the area. This section features a specific discharge rate of $10.2 \mathrm{dm}^{3} \mathrm{~s}^{-1} \mathrm{~km}^{-2}$ and an average annual discharge rate of $1.6 \mathrm{~m}^{3} \mathrm{~s}^{-1}$. The middle section of the river is characterized by human impact in the form of the use of water resources for energy generation purposes (sawmills, gristmills, power plants) and occasionally irrigation purposes. This section features an average annual discharge rate 
of $3.8 \mathrm{~m}^{3} \mathrm{~s}^{-1}$, with $\mathrm{q}=10.4 \mathrm{dm}^{3} \mathrm{~s}^{-1} \mathrm{~km}^{-2}$, and a hydraulic gradient of $2 \%$.

The lower section of the Eupawa that includes Lake Gardno is characterized by significant changes in water relationships associated with difficult discharge conditions. This section functions as a receiving area for water coming in from all parts of the river's drainage basin including surface waters and groundwater. This stretch of the river features an elevated rate of discharge of $8.3 \mathrm{~m}^{3} \mathrm{~s}^{-1}$ and $\mathrm{q}=12.8 \mathrm{dm}^{3} \mathrm{~s}^{-1} \mathrm{~km}^{-2}$. In addition, it is sporadically affected by seawater intrusions. Finally, the mouth section of the river, given its location, has been adapted as a port facility.

In the end answering questions asked the work at the beginning if can one infer the type of human impact found in the northern Pomorze region from the current state of the Łupawa basin we can say that by the type of man's activities in the catchment river Łupawa it is not possible to file about it. The completely different influence of the man is watching each other in the entire region and other in the bottom part of the catchment river Łupawa (Smołdzino-Rowy). Similar observations were taken note in the Vistula delta (Fac-Beneda 2005b, Fac-Beneda et al. 2005). Answering the second question did regional water relationships determine the type of human impact found in the area we can say that water relationships are conditioning antropopresion, rather than inversely.

\section{References}

BogdANOWicz R., 2004. Hydrologiczne uwarunkowania transportu wybranych zwiazków azotu i fosforu Odra i Wista oraz rzekami Przymorza do Battyku (Hydrological factors influencing transport of selected nitrogen and phosphorus compounds from the Odra River, the Vistula River and Polish coastal rivers to the Balic Sea). Wydawnictwo UG, Gdańsk.

BoRóWKa R.K., 1995. Sub-Quaternary surface and main Quaternary series in the Gardno-Łeba Coastal Plain. In: K. Rotnicki (ed.), Changes of the Polish Coastal Zone. GuideBook of the Field Symposium IGU CCS Polish Coast'94, Poznań: 221-223.

Choiński A. \& KANIECKi A., 2003. Plan ochrony Stowińskiego Parku Narodowego (Protecion Plan of the Slovincian National Park). Tom IV, Poznań (manuscript).

CieślińsKi R. \& DrWal J., 2005. Quasi-estuary processes and consequences for human activity, South Baltic, Estuarine. Coastal and Shelf Science 62: 477-485.

CYBERSKI J. \& JęDRASIK J, 1992. Wymiana i cyrkulacja wód w jeziorze Gardno (The exchange and the circulation of waters in the lake Gardno). In: K. Korzeniewski (ed.), Zlewnia przymorskiej rzeki Łupawy i jej jeziora. Słupsk.

DRWAL J., 1982. Wykształcenie i organizacja sieci hydrograficznej na terenach młodoglacjalnych (Producing and the organization of the hydrographical network on youngglacial areas). Zeszyty Naukowe UG 33, Wydawnictwo UG, Gdańsk.

Drwal J. \& HryniszaK E., 2003. Hydrologiczne funkcje zagłębień bezodpływowych na terenach młodej akumulacji lodowców skandynawskich (Hydrological functions of no outflow hollows on areas of the young accumulation of Scandinavian glaciers). In: A. Kostrzewski (ed.), Funkcjonowanie geoekosystemów zlewni rzecznych. Obieg wody, uwarunkowania i skutki w środowisku przyrodniczym. Bogucki Wyd. Nauk., Poznań.

Drwal J., Cieśliński R. \& Chlost I., 2007. Obieg wody w jeziorze przybrzeżnym na przykładzie jeziora Łebsko (Circulation of water in the coastal lake on the example of the lake Łebsko). In: Z. Michalczyk (ed.), Obieg wody w środowisku naturalnym i przekształconym. Badania hydrograficzne w poznawaniu środowiska. Tom VIII, Wydawnictwo UMCS, Lublin: 185-193.

FAC-BENEDA J., 2005a. Wielkość odpływu ze zlewni niekontrolowanych hydrometrycznie określona metodą redukcji na przykładzie dorzecza Łupawy i Słupi (Size of the outflow from the hydrometric unchecked drainage areas determined by the method of the reduction on the example of the Łupawa and Słupia river basin). In: A. Kostrzewski \& R. Kolander (eds), Zintegrowany monitoring środowiska przyrodniczego. Funkcjonowanie geoekosystemów Polski w warunkach zmian klimatu i różnokierunkowej antropopresji. Biblioteka Monitoringu Środowiska, Poznań.

FAC-BENEDA J., 2005b. Hydrographic structure of the eastern part of the Vistula Delta. Peribalticum, IX, GTN, Gdańsk: 79-91.

FAC-BEnEDA J., 2007. Formowanie się i organizacja odpływu w systemie Słupi, Łupawy i Łeby (Forming and the organization of the drain hole in the Słupia, Łupawa and Łeba system). In: Z. Michalczyk (ed.), Obieg wody w środowisku naturalnym i przekształconym. Badania Hydrograficzne w poznawaniu środowiska. Tom VIII, Wydawnictwo UMCS, Lublin: 203-210.

Fac-Beneda J., CieślińsKi R. \& Drwal J., 2005. Melioration systems of the Vistula Delta, The Geographical Yearbook, (Geografijos Metraštis), XXXVIII (2), Vilnius: 39-44.

FLOREK W., 1993. Główne etapy rozwoju koryt i dolin rzecznych środkowego Przymorza w późnym vistulianie i holocenie (Main stages of the evolution of channels and river valleys of Pomerania centre in late Vistulian and Holocene). In: Geologia i geomorfologia środkowego Pobrzeża i Południowego Bałtyku. WSP, Słupsk: 279-301.

JeRECZEK-KorZENIEWSKA K, 2005. Stan zabudowy hydrotechnicznej na rzece Łupawie (State of hydrotechnical constructions on the river Łupawa). In: J.P. Giriatowicz \& Cz. Koźmiński (eds), Hydrograficzne i meteorologiczne aspekty badań wybrzeża Battyku i wybranych obszarów Polski. Oficyna Uniwersytet Szczeciński, Instytut Nauk o Morzu, Szczecin: 50-58.

KARCZEWSKI A., 1988. Układ przestrzenny morenowych poziomów wysoczyznowych północnego skłonu Pomorza jako rezultat zróżnicowanej deglacjacji (Spatial arrangement of moraine levels of north bend of Pomerania of the deglaciation as the diversified result). Badania Fizjograficzne nad Polska Zachodnia XXXVIII, Seria A, Geografia Fizyczna, Poznań. 
MARSZELEWSKi W., 2007. Zróżnicowanie zasobów wód powierzchniowych dorzeczy Przymorza (Diversifying resources of surface waters of Pomerania river basins). In: Z. Michalczyk (ed.), Obieg wody w środowisku naturalnym i przeksztatconym, Tom VIII, Wydawnictwo UMCS, Lublin: 361-371.

RotNICKI K., 2001. Stratygrafia i paleogeografia vistulianu Niziny Gardnieńsko-Łebskiej (Vistulian stratygraphy and paleogeography of the Gardnieńsko-Łebska Lowland). In: K. Rotnicki (ed.), Przemiany środowiska geograficznego nizin nadmorskich potudniowego Battyku w vistulianie i holocenie. Bogucki Wyd. Nauk., Poznań: 19-30.

SylweStRZAK J., 1978. Rozwój sieci dolinnej na Pomorzu pod koniec plejstocenu (Evolution of the lowland network on Pomerania at the end of the Pleistocene). GTN. Gdańsk. 